UNDERGRADUATE RESEARCH IN NATURAL AND CLINICAL SCIENCE AND TECHNOLOGY (URNCST) JOURNAL Read more URNCST Journal articles and submit your own today at: https://www.urncst.com

\title{
The Effect of Exercise on Reducing Tumor Necrosis Factor Alpha Levels and Attenuating Serotonin Transporter Gene Expression: A Research Protocol
}

\author{
Janany Gunabalasingam, BHSc Student [1]*, Kajol Aggarwal, BHSc Student [1] \\ [1] Faculty of Health Sciences, McMaster University, Hamilton, Ontario, Canada L8S 4L8 \\ *Corresponding Author: gunabalj@mcmaster.ca
}

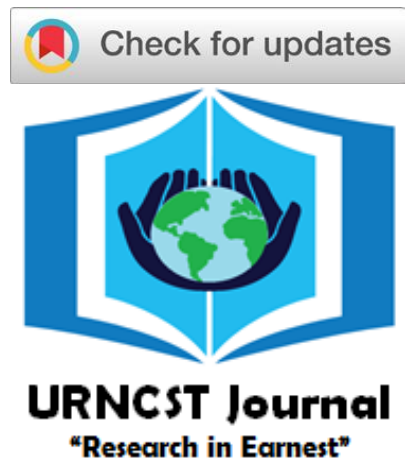

\begin{abstract}
Introduction: The intricate relation between depression and inflammation has become a prevalent topic of discussion among the scientific community. Pro-inflammatory cytokines exert depressogenic effects by crossing the blood brain barrier and disrupting serotonin (5-hydroxytryptamine, 5-HT) homeostasis through serotonin transporters (SERTs). SERTs induce 5-HT reuptake, causing 5-HT deficiency. This study demonstrates that (1) exercise decreases levels of the pro-inflammatory cytokine, Tumor Necrosis Factor alpha (TNF- $\alpha$ ), and (2) a decline in TNF- $\alpha$ attenuates SERT activity through the proposed mechanism of activating the p38 mitogen-activated protein kinase (MAPK) pathway in the hippocampus.

Methods: 32 Sprague-Dawley rats are randomly divided into four groups. Rats not exercising serve as control. Exercising rats, exposed to 6 weeks of treadmill exercise, receive either vehicle intracerebroventricular injection, intracerebroventricular injection of TNF- $\alpha$ antibody Infliximab, or intracerebroventricular injection of MAPK inhibitor SB203580. Control rats also receive vehicle intracerebroventricular injection. 24 hours post-injection, blood is collected, and serum is separated for an ELISA test to assess TNF- $\alpha$ levels. To measure SERT gene expression, RNA is isolated from hippocampal tissue and PCR is performed.

Results: Exercising rats are anticipated to show reduced TNF- $\alpha$ levels compared to control, confirming exercise decreases pro-inflammatory cytokines. Exercising rats should also show decreased SERT gene expression, as exercise attenuates TNF$\alpha$ mediated stimulation of SERTs. SERT expression is expected to be similar in rats injected with Infliximab and SB203580, suggesting that TNF- $\alpha$ exerts its effect through the p38 MAPK pathway.

Discussion: Moderate intensity exercise reduces TNF- $\alpha$ levels, which limits 5-HT uptake by attenuating the expression of the SERT gene, thus mitigating depressive symptoms. It is also postulated that TNF- $\alpha$ modulates levels of SERT expression through the p38 MAPK pathway, as rats injected with SB203580 have shown to have similar gene expression as rats injected with Infliximab.

Conclusion: Understanding the negative correlation between exercise and depression provides insight into viable treatment alternatives for depression. Exercise may be used alone or in conjunction with current treatments to prevent or minimize symptoms of mood disorders. Further investigation may reveal the effects of other cytokines on extracellular 5-HT levels, and their consequent influence on depression and its symptoms.
\end{abstract}

Keywords: depression; exercise; TNF- $\alpha$; SERT; p38 MAPK

\section{Introduction}

Depression is one of the most common mental disorders worldwide, with over 264 million people affected [1]. It is characterized by persistent feelings of sadness and anhedonia, and its symptoms may include fatigue, diminished ability to concentrate, and changes in appetite. Depressive symptoms may cause distress to the point where they can impair social or occupational functioning [2]. According to the Ontario Ministry of Health, one in four Canadians have experienced depressive symptoms that were severe enough to require treatment at least once in their life [3]. Many genetic and psychological vulnerabilities can result in the pathogenesis of depression, including the presence of certain genes, dysfunction of specific brain systems, and stressful life events [2]. Various neurobiological mechanisms have been implicated in the onset of depression, each involving the underlying notion that depressive symptoms are caused by a functional deficiency of brain monoaminergic transmitters, specifically serotonin, norepinephrine, and dopamine [4]. This study focuses on the role of dysregulation of central serotonin (5-hydroxytryptamine, 5-HT) homeostasis on the pathophysiology of depression, as serotonin transporters (SERTs) may induce 5-HT uptake and result in its deficiency. 5-HT has been widely implicated in regulating mood, eating, and sleeping patterns, therefore making it the key neurotransmitter of interest in this study. 
UNDERGRADUATE RESEARCH IN NATURAL AND CLINICAL SCIENCE AND TECHNOLOGY (URNCST) JOURNAL Read more URNCST Journal articles and submit your own today at: https://www.urncst.com

Changes in SERT activity impact 5-HT availability in target areas, therefore affecting a host of neuronal functions [4]. With a prominent role in the regulation of 5-HT, SERTs are a common pharmacological target for antidepressants. In recent years, studies have demonstrated several mechanisms involved in the regulation of SERT activity, including protein kinases and phosphatase dependent pathways [4]. Some of these pathways are initiated with immune modulators, particularly proinflammatory cytokines. These findings suggest the prevalent role of the immune system and cytokines in depression through the regulation of SERTs.

Cytokines are essential to brain development and functioning, as they play an important role in supporting neuronal integrity, neurogenesis, and synaptic remodeling [5]. Cytokines can affect neurotransmitter systems and consequently produce behavioral alterations, including changes in motivation, arousal, and anxiety. Acute administration of inflammatory cytokines can engage the innate immune system and induce an adaptive behavioral response known as "sickness behavior," which may involve fever, loss of appetite, lethargy, changes in sleep pattern, anhedonia, and decreased social interaction [5]. These responses to inflammatory cytokines may be beneficial in order to allow for the conservation of energy and combat infection. However, chronic exposure to elevated levels of inflammatory cytokines can cause significant alterations in neurotransmitter systems and function, resulting in neuropsychiatric dysfunction and development of disorders, particularly depression. Recent studies have confirmed increased rates of depression among those who have elevated levels of inflammatory cytokines [5]. Such behavioural effects manifest through cytokine-induced activation of inflammatory signalling pathways in the brain, resulting in alterations in monoamine and glutamate systems, while also depleting levels of essential growth factors [5].

Due to their effects on monoamine systems, inflammatory cytokines are particularly known to alter the metabolism and release of 5-HT in the central nervous system (CNS) [6]. Meta-analytic research has shown that moderate intensity exercise can reduce levels of proinflammatory cytokines [6]. Physical exercise activates the immune system, and regular exercise of moderate intensity promotes an anti-inflammatory status, which is an important factor in improving health [6]. Past studies have consequently examined the efficacy of exercise as a behavioural intervention in alleviating depressogenic symptoms, with the majority indicating that it is effective [5].

The pro-inflammatory cytokine of interest in this study is Tumor Necrosis Factor alpha (TNF- $\alpha$ ). Recent meta-analyses confirmed that circulating levels of TNF- $\alpha$ are significantly higher in depressed patients compared with healthy control subjects [7]. The binding of TNF- $\alpha$ to astrocyte surface receptors in the brain results in a dose and time dependent increase in SERT-mediated 5-HT uptake [8]. To further understand the effect of TNF- $\alpha$ on SERT gene expression, Infliximab, an $\operatorname{IgG} 1 \kappa$ monoclonal antibody, is administered in the study [9]. Infliximab binds to TNF- $\alpha$ with high affinity to block interaction with its receptor and disrupt the pro-inflammatory signalling cascade, thereby reducing the activation of the pathway responsible for SERT gene expression [9]. Administration of Infliximab is hypothesized to decrease SERT gene expression compared to TNF- $\alpha$, highlighting the prominent role of this cytokine in serotonin homeostasis.

This study catalyzes the need for further analysis of p38 MAPK kinases and their mediative role on SERT gene expression. P38 MAPK kinases are primarily activated through extracellular stressors and cytokines, and are extensively studied in the field of inflammation [10]. Cytokines, such as TNF- $\alpha$, activate the p38 MAPK pathway through cell surface receptors on microglia and astrocytes, consequently engaging in multiple signal transduction pathways involving the alteration of gene expression [10]. This study investigates how exercise can alter TNF- $\alpha$ levels, and how TNF- $\alpha$ levels can in turn have an effect on SERT gene expression. Considering the prominent role of TNF- $\alpha$ in the p38 pathway, it is postulated that the decrease in TNF- $\alpha$ levels with exercise may alter SERT expression through this pathway [11]. To understand the possible relationship between p38 MAPK and SERT gene expression, injections of SB203580 are administered to one group of exercising experimental rats. SB203580 selectively inhibits p38 catalytic activity by binding to the ATP binding pocket and preventing its phosphorylation, consequently inhibiting the downstream activation of the pathway $[12,13]$.

\section{Objective}

Proinflammatory cytokines and serotonergic homeostasis have been implicated in the pathogenesis of depression. The aim of this study is to determine (1) how regular exercise alters levels of the proinflammatory cytokine, TNF- $\alpha$, and (2) how changes in TNF- $\alpha$ levels alter the expression of SERT genes [14, 15]. With reduced expression of SERTs, less 5-HT is removed from the synaptic cleft, improving depressogenic conditions. Through this study, it is postulated that TNF- $\alpha$ exerts its effect through the p38 MAPK pathway [11]. Relevant connections between exercise, proinflammatory cytokines, and SERT gene expression suggest alternative practices that can be applied in conjunction with treatments to prevent or mitigate depressive symptoms. 
UNDERGRADUATE RESEARCH IN NATURAL AND CLINICAL SCIENCE AND TECHNOLOGY (URNCST) JOURNAL Read more URNCST Journal articles and submit your own today at: https://www.urncst.com

\section{Methods}

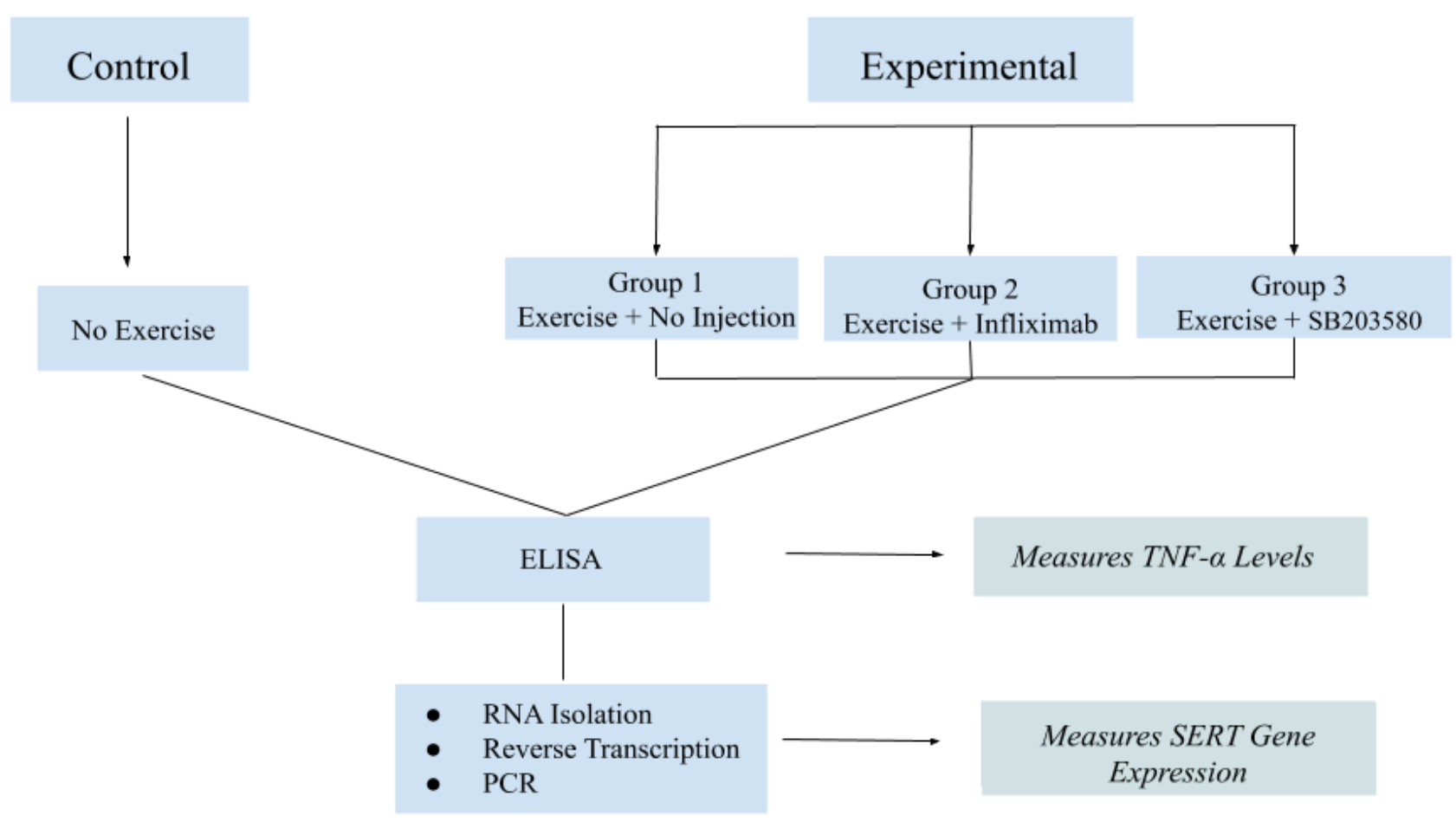

Figure 1. Overview of Experiment

Preparation of Rat Models

Sprague-Dawley rats are housed in groups of 4 in polyethylene cages, in a laboratory at controlled temperatures $\left(21 \pm 1^{\circ} \mathrm{C}\right)[16]$. Rats are maintained under a 12 $\mathrm{h}$ light-dark cycle (lights on at 07:00 h, with a 30 minute dim and rise phase) [16]. All rats are naive to experimental procedures, and food and water is available ad libitum. Procedures are in accordance with the guidelines of the Canadian Council on Animal Care [16].

\section{Reagents}

TNF- $\alpha$, TNF- $\alpha$ inhibitor Infliximab, and MAPK inhibitor SB203580 are purchased from Santa Cruz Biotechnology Inc $[9,12,17]$.

\section{Treatment Groups}

The 32 rats are randomly divided into four groups. Rats not exercising (Group 1) serve as control. The remaining exercising rats are exposed to 6 weeks of moderate intensity treadmill exercise for 30 minutes/day, 5 days/week. Longterm ( $>2$ weeks) treadmill exercise has been shown to suppress oxidative stress and microglia-induced neuroinflammation by decreasing TNF- $\alpha$ levels [18]. Following the 6 week period, control rats receive vehicle intracerebroventricular (ICV) injection, and exercising rats receive either vehicle ICVinjection (Group 2), ICV injection of TNF- $\alpha$ antibody Infliximab (Group 3), or ICV injection of MAPK inhibitor SB203580 (Group 4).
Intracerebroventricular Injection

The fully developed blood brain barrier prevents the drugs from reaching the brain following injection, consequently making intravenous delivery ineffective [19]. ICV injection allows for delivery directly into cerebral lateral ventricles and into the CNS through the cerebrospinal fluid [19]. This method has been used in numerous studies to introduce drugs, therapeutic RNAs, and viral vectors into the CNS of animal models [19]. Furthermore, previous studies have successfully used ICV injection of Infliximab and SB203580 at a dose of $5 \mathrm{mg} / \mathrm{kg}$ of body weight in order to demonstrate their protective effects on neuropathology [20]. The injection does not require extensive surgical devices and can be performed by a single person [19].

Both Infliximab and SB203580 are administered at $5 \mathrm{mg} / \mathrm{kg}$ of body weight after 6 weeks of exercise [16]. A 30-gauge needle attached to a 5-ml Hamilton syringe through long polyethylene tubing is used [21]. The needle is inserted $2 \mathrm{~mm}$ deep and perpendicular to the skull surface, in order to ensure effective entry into the ventricle. It is inserted approximately $0.25 \mathrm{~mm}$ lateral to the sagittal suture and $0.50-0.75 \mathrm{~mm}$ rostral to the coronal suture to allow for exact penetration into the ventricle [21]. The needle is left in place for 1 minute following the discontinuation of plunger movement to ensure that the entire injection is delivered and prevent backflow [21]. 
UNDERGRADUATE RESEARCH IN NATURAL AND CLINICAL SCIENCE AND TECHNOLOGY (URNCST) JOURNAL Read more URNCST Journal articles and submit your own today at: $\underline{\text { https://www.urncst.com }}$

\section{Expression of TNF- $\alpha$}

24 hours post-injection, enzyme-linked immunosorbent assay (ELISA) is used to assess serum levels of TNF- $\alpha$ in both control and exercising groups. Blood is collected using a gauge needle and centrifuged for 10 minutes in sterile tubes [22]. The serum layer is separated from the blood and stored at $-20^{\circ} \mathrm{C}$ until the test day. Using an ELISA kit purchased from ThermoFisher, the serum sample is mobilized to the microplate [23]. In the first incubation, specific antibodies for TNF- $\alpha$ are added and then washed to remove any unbound antibodies. In the second incubation, secondary antibodies are added and then washed. A substrate solution is added to interact with the enzyme on the secondary antibody to generate visible colour [22]. Appropriate hardware, as indicated by plate reader manufacturers, is used to measure absorbance. Absorbance vs. concentration of TNF-a is obtained for each group [24].

\section{Expression of SERT Genes}

To assess SERT gene expression in both control and exercising groups, hippocampal tissue is isolated from the rat models. The rats are anesthetized hippocampal tissue is collected within 24 hours of blood collection.

RNA is isolated from brain tissue using the Qiazol Reagent Method [25]. Tissue samples are homogenized with a lysis reagent purchased from QIAzol. With the addition of chloroform, the homogenate is separated into aqueous and organic phases by centrifugation [26]. The RNA is partitioned to the aqueous phase, DNA partitioned to the interphase and proteins are partitioned to the organic phase. RNA is precipitated from the aqueous phase using isopropanol, and then purified using the RNeasy MinElute Cleanup Kit purchased from QIAzol [26].

Reverse transcription reaction is used to synthesize cDNA with a commercial kit [27]. The cDNA is diluted with water and then amplified in a PCR reaction.

Amplification of SERT mRNA is performed using the following primers: 5'-CAGCATCTGGAAAGGCGTCA AGACC-3' and 5'- AGTGGACGCTGGATGTTGGC TATC-3. Several cycles of PCR is conducted [27]. The amplified cDNA fragments are analyzed using electrophoresis in polyacrylamide gels. The intensity of DNA bands is measured using PhosphorImager, thereby showing the levels of SERT expression [27].

\section{$\underline{\text { Statistical Analysis }}$}

All experiments are conducted at least three times. Statistical analysis, such as analysis of variance (ANOVA) is performed to note statistical differences between the four groups [17]. ANOVA tests are conducted to observe if there are significant differences in TNF-a levels and mRNA expression between the control and experimental groups.

\section{Results}

This study proposed by the protocol has not been started. This section will outline the study timeline and anticipated results.

\section{Expression of TNF- $\alpha$}

Exercising rats are expected to show reduced TNF- $\alpha$ levels compared to control, confirming exercise decreases pro-inflammatory cytokines [14].

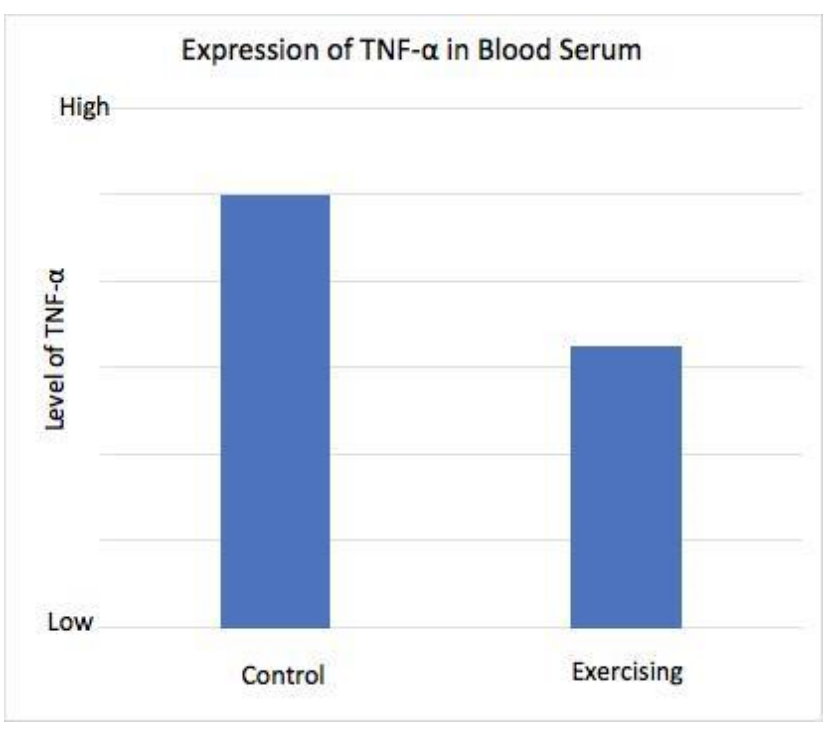

Figure 2. Anticipated results of expression of TNF- $\alpha$ in all exercising rats compared to control

\section{SERT Gene Expression}

Exercising rats should show decreased SERT gene expression compared to control, as exercise attenuates TNF- $\alpha$ mediated stimulation of SERT [15]. The magnitude of SERT gene expression may vary amongst the three exercising groups. It is expected to be lower in rats injected with Infliximab and SB203580 compared to those who exercised but received a vehicle injection. Furthermore, SERT expression is expected to be similar (i.e. decrease by similar magnitude) in rats injected with Infliximab and SB203580, indicating TNF- $\alpha$ exerts its effect through the p38 MAPK pathway.

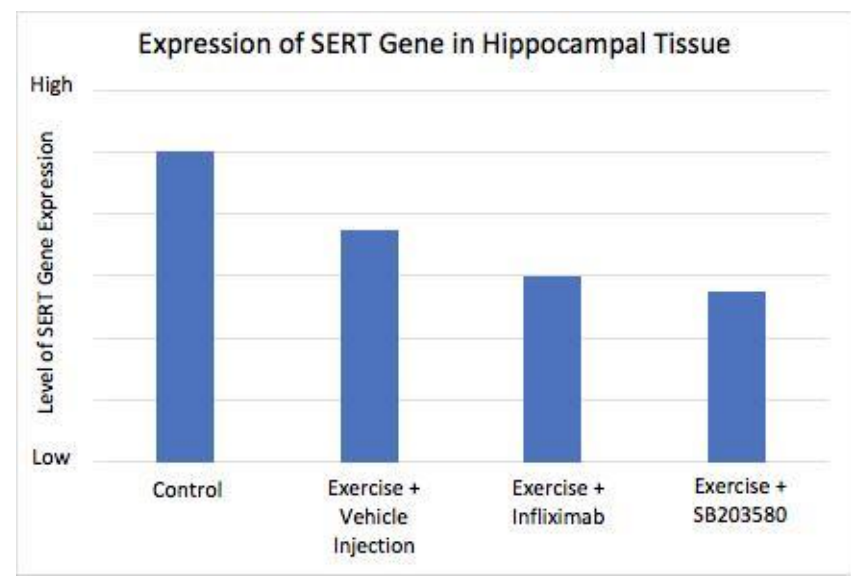

Figure 3. Anticipated results of SERT gene expression 
UNDERGRADUATE RESEARCH IN NATURAL AND CLINICAL SCIENCE AND TECHNOLOGY (URNCST) JOURNAL Read more URNCST Journal articles and submit your own today at: https://www.urnest.com

\section{Discussion}

In this study, the role of exercise on depression is studied through the presence of pro-inflammatory cytokines, specifically TNF- $\alpha$. Firstly, all exercising rats show reduced TNF- $\alpha$ levels compared to control, confirming exercise decreases pro-inflammatory cytokines [14]. The role of TNF- $\alpha$ on SERT gene expression is then studied using a process of RNA isolation from hippocampal tissue and PCR reaction [24,27]. Compared to the control, exercising rats show decreased SERT gene expression. This confirms the second focus of this study, demonstrating the relationship between low levels of proinflammatory cytokines and reduced SERT gene expression [15]. Combining these two findings indicates that exercise reduces TNF- $\alpha$ levels, thereby limiting 5-HT uptake through reduced SERT gene expression.

Changes in SERT gene expression are observed amongst the three exercising groups: those receiving vehicle injection, injection with Infliximab, or injection with SB203580. SERT expression is expected to be lower in all 3 exercising groups compared to control because exercise lowers TNF- $\alpha$-mediated stimulation of SERT [15]. Rats receiving injection of Infliximab and SB203580 should show a similar decrease in SERT expression following exercise, consequently highlighting the relationship between both compounds. Infliximab prevents TNF- $\alpha$ from binding to its receptor and exerting its effect, thus limiting SERT expression [9]. If expression after injection of Infliximab is similar to expression after injection of SB203580, it is plausible that TNF- $\alpha$ exerts its effect through the p38 MAPK pathway, since inhibiting the pathway also lowers SERT expression by a similar extent [11]. Furthermore, it is anticipated that although similar, there will be a slightly lower expression of SERT in exercised rats injected with SB203580 compared to exercise rats with Infliximab, due to SB203580's direct interaction with p38 MAPK [11].

Understanding the relationship between exercise and depression provides insight into possible treatments that can mitigate depressive symptoms. Over half of the people experiencing depression have recurrent depressive episodes and suffer from chronic depression [1]. This sparks the need for further research on possible prevention, treatment, and management strategies [28]. Currently, people with depression generally only receive pharmacologic treatment such as antidepressants. However, studies suggest the importance of incorporating cognitive-behavioural therapies into existing treatment as a means for better patient outcomes [28]. As such, this study considered the role of exercise on SERT gene expression, an area of target in depressive symptoms.

In a study involving the administration of selfassessment questionnaires on adults ages 18-45 years to assess anxiety and depression levels, physical exercise was significantly associated with lower depression levels [28]. Furthermore, another study found that exercise reduced depressive symptoms among adults, and regular exercise was associated with reduced levels of Interleukin-6 after 2 weeks [29]. These findings demonstrate the effect of exercise on reducing inflammatory cytokine levels and depressive symptoms. The proposed study corroborates these findings, while also demonstrating the effect of inflammatory cytokines on SERT gene expression and consequent central serotonin uptake, therefore showing the direct manner by which exercise-induced attenuation of inflammatory cytokines can reduce depressive symptoms.

Animal models may not reflect phenomena in humans. An alternate study can be conducted on humans using a randomized control trial, in which adults experiencing depressive symptoms are randomly divided into 2 intervention groups: those who will be subject to regular, moderate-intensity exercise, and a control group that will do nothing. A questionnaire will be administered to both groups after 3 weeks, 6 weeks, and 12 weeks in order to evaluate changes in depressive symptoms. Analysis of results can demonstrate the direct relationship between exercise and depression, although this study will provide no mechanistic explanations.

A limitation of this study is that it only tests the effects of exercise on TNF- $\alpha$ and SERT. TNF- $\alpha$ has two cell surface receptors, CD120a and CD120b [30]. It binds with higher affinity to CD120a, which plays a role in inflammatory regulation and activates three groups of MAP kinases: extracellular-signal-regulated kinases (ERKs), cJun NH2-terminal kinases (JNKs), and p38 MAP kinases $[11,30]$. Therefore, it is possible that TNF- $\alpha$ exerts its effect through one of these other pathways rather than only activating p38 MAP kinases. However, our study would suggest that it is likely for TNF- $\alpha$ to engage the p38 MAPK cascade, since inhibiting this pathway would produce a similar result as inhibiting TNF- $\alpha$ from binding to its receptor, consequently indicating the relationship between TNF- $\alpha$ and $\mathrm{p} 38$.

To further strengthen the relationship between exercise, inflammation and depression, the p38 MAPK pathway should be further explored. A possible study could involve a petri dish experiment with RN46A cells - a serotonergic neuronal cell line [17]. A western blot analysis can be performed to compare SERT protein levels in a control group and exercising groups with either TNF- $\alpha$, or TNF- $\alpha+$ SB203580 [17]

\section{Conclusion}

Studying the relationship between physical exercise, proinflammatory cytokines and SERT gene expression provides valuable insight into the underlying mechanisms of depression. Through experimental procedures conducted on rat models, this study will demonstrate that moderate intensity exercise reduces levels of TNF- $\alpha$, and reduced levels of TNF- $\alpha$ limit 5-HT uptake by attenuating the expression of the SERT gene. It is also postulated that TNF- $\alpha$ modulates levels of SERT expression through the 
UNDERGRADUATE RESEARCH IN NATURAL AND CLINICAL SCIENCE AND TECHNOLOGY (URNCST) JOURNAL Read more URNCST Journal articles and submit your own today at: https://www.urncst.com

p38 MAPK pathway, as rats injected with SB203580 have shown to have similar gene expression as rats injected with Infliximab. Further experiments should be conducted to strengthen the relationship between $\mathrm{TNF}-\alpha$ and the $\mathrm{p} 38$ MAPK pathway. Understanding the negative correlation between exercise and depression also suggests an effective behavioural intervention that may be used as a preventative measure, or in conjunction with existing treatment in order to further mitigate depressogenic symptoms.

List of Abbreviations Used

ANOVA: analysis of Variance

CNS: central nervous system

ELISA: enzyme-linked immunosorbent assay

GFAP: glial fibrillary acidic protein

5-HT: 5-hydroxytryptamine

ICV: intracerebroventricular

MAPK: mitogen-activated protein kinase

NET: norepinephrine transporter

PCR: polymerase chain reaction

SERT: serotonin transporter

TNF- $\alpha$ : tumor necrosis factor alpha

\section{Conflicts of Interest}

The authors declare that they have no conflicts of interest.

\section{Ethics Approval and/or Participant Consent}

This study did not require an ethics approval as it is a research protocol and no humans, animals, tissues were used in the process.

\section{Authors' Contributions}

JG: Made substantial contributions to the design of the study, collection, interpretation and analysis of data, revised the manuscript critically, and gave final approval of the version to be published.

KA: Made substantial contributions to the design of the study, collection, interpretation and analysis of data, revised the manuscript critically, and gave final approval of the version to be published.

\section{Acknowledgements}

We would like to thank URNCST Journal Mentored Paper Initiative for inviting us to write a full manuscript.

\section{References}

[1] Depression [Internet]. Who.int. 2020 [cited 14 November 2020]. Available from: https://www.who.int/ news-room/fact-sheets/detail/depression

[2] Depression Definition and DSM-5 Diagnostic Criteria [Internet]. Psycom.net - Mental Health Treatment Resource Since 1996. 2020 [cited 14 November 2020]. Available from: https://www.psycom.net/depressiondefinition-dsm-5-diagnostic-criteria/
[3] Depression - Mental Health - Publications - Public Information - MOHLTC [Internet]. 2020 [cited 14 November 2020]. Available from: http://www.health.gov.on.ca/en/public/publications/ment al/depression.aspx

[4] Bowman M, Daws L. Targeting Serotonin Transporters in the Treatment of Juvenile and Adolescent Depression. Frontiers in Neuroscience. 2019 Feb 27;13(156):1-14. https://doi.org/10.3389/fnins.2019.00156

[5] Felger, J. and Lotrich, F., 2013. Inflammatory cytokines in depression: Neurobiological mechanisms and therapeutic implications. Neuroscience. 2013 May 3;246:199-229. https://doi.org/10.1016/j.neuroscience .2013 .04 .060

[6] Scheffer D, Latini A. Exercise-induced immune system response: Anti-inflammatory status on peripheral and central organs. Biochimica et Biophysica Acta (BBA) Molecular Basis of Disease. 2020 Apr 29;1866(10):115. https://doi.org/10.1016/j.bbadis.2020.165823

[7] Maeng S, Hong H. Inflammation as the Potential Basis in Depression. International Neurourology Journal. 2019 Nov 30;23(Suppl 2):S63-71. https://doi.org/10.5213/ inj.1938226.113

[8] Inazu M, Takeda H, Ikoshi H, Sugisawa M, Uchida Y, Matsumiya T. Pharmacological characterization and visualization of the glial serotonin transporter. Neurochemistry International. 2001 Jul;39(1):39-49. http://doi.org/10.1016/s0197-0186(01)00010-9

[9] Rheumatoid Arthritis : Anti-TNF Therapy for the Treatment of RA [Internet]. Johns Hopkins Arthritis Center. 2020 [cited 14 November 2020]. Available from: https://www.hopkinsarthritis.org/arthritis-info/ rheumatoid-arthritis/ra-treatment/anti-tnf-therapy-for-ra/

[10] Corrêa S, Eales K. The Role of p38 MAPK and Its Substrates in Neuronal Plasticity and Neurodegenerative Disease. Journal of Signal Transduction. 2012;2012:1-12. S, Eales K. The Role of p38 MAPK and Its Substrates in Neuronal Plasticity and Neurodegenerative Disease. Journal of Signal Transduction. 2012;2012:1-12.

[11] Sabio G, Davis R. TNF and MAP kinase signalling pathways. Seminars in Immunology. 2014;26(3):237245. https://doi.org/10.1016/j.smim.2014.02.009

[12] Xiao Y, Yan W, Cao Y, Yan J, Cai W. P38 MAPK Pharmacological Inhibitor SB203580 Alleviates Total Parenteral Nutrition-Induced Loss of Intestinal Barrier Function but Promotes Hepatocyte Lipoapoptosis. Cellular Phy siology and Biochemistry. 2017;41(2):623634. https://doi.org/10.1159/000457933

[13] MAPKAPK2 Gene - GeneCards | MAPK2 Protein | MAPK2 Antibody [Internet]. Genecards.org. 2020 [cited 14 November 2020]. Available from: https://www.genecards.org/cgi-bin/carddisp.pl?gene= MAPKAPK2

[14] Moon M, Cho B, Lee Y, Choi S, Lim S, Park K et al. The effects of chronic exercise on the inflammatory 
UNDERGRADUATE RESEARCH IN NATURAL AND CLINICAL SCIENCE AND TECHNOLOGY (URNCST) JOURNAL

Read more URNCST Journal articles and submit your own today at: https://www.urncst.com

cytokines interleukin- 6 and tumor necrosis factor- $\alpha$ are different with age. Applied Physiology, Nutrition, and Metabolism. 2012 Aug;37(4):631-636. https://doi.org/ 10.1139/h2012-039

[15] Malynn S, Campos-Torres A, Moynagh P, Haase J. The Pro-inflammatory Cytokine TNF- $\alpha$ Regulates the Activity and Expression of the Serotonin Transporter (SERT) in Astrocytes. Neurochemical Research. 2013 Apr;38(4):694-704. https://doi.org/10.1007/s11064012-0967-y

[16] Triantafillidis, J., 2005. Favorable response to subcutaneous administration of infliximab in rats with experimental colitis. World Journal of Gastroenterology. 2005 Nov 21;11(43):6843-6847.https://doi.org/ 10.3748/wjg.v11.i43.6843

[17]Zhu C, Blakely R, Hewlett W. The Proinflammatory Cytokines Interleukin-1beta and Tumor Necrosis Factor-Alpha Activate Serotonin Transporters. Neuropsychopharmacology. 2006 Feb 1;31(10):21212131. https://doi.org/10.1038/sj.npp.1301029

[18] Mee-inta O, Zhao Z, Kuo Y. Physical Exercise Inhibits Inflammation and Microglial Activation. Cells. 2019 Jul 9;8(7):691. $\quad$ https://doi.org/https://doi.org/ 10.3390/cells 8070691

[19] Glascock J, Osman E, Coady T, Rose F, Shababi M, Lorson C. Delivery of Therapeutic Agents Through Intracerebroventricular (ICV) and Intravenous (IV) Injection in Mice. Journal of Visualized Experiments. 2011 Oct 3;(56):1-4. https://doi.org/10.3791/2968

[20] Kübra Elçioğlu, H., Kabasakal, L., Tufan, F., Elçioğlu, Ö., Solakoglu, S., Kotil, T. and Karan, M., 2015. Effects of systemic Thalidomide and intracerebroventricular Etanercept and Infliximab administration in a Streptozotocin induced dementia model in rats. Acta Histochemica, 117(2), pp.176-181.

[21] Gholizadeh, S., Tharmalingam, S., MacAldaz, M. and Hampson, D., 2013. Transduction of the Central Nervous System After Intracerebroventricular Injection of Adeno-Associated Viral Vectors in Neonatal and Juvenile Mice. Human Gene Therapy Methods. 2013 Aug 3;24(4):205-213. https://doi.org/10.1089/hgtb .2013 .076

[22] Rani S, Barbe M, Barr A, Litivn J. Role of TNF alpha and PLF in bone remodeling in a rat model of repetitive reaching and grasping. Journal of Cellular
Physiology. 2010 Oct;225(1):152-167.https://doi.org/ $10.1002 / j \mathrm{jcp} .22208$

[23] Kara Y. The measurement of serum tumor necrosis factor-alpha levels in patients with lichen planus. Indian Journal of Dermatology. 2018 Jul-Aug;63(4):297-300. https://doi.org/10.4103/ijd.IJD_474_17

[24] ELISA technical guide and protocols [Internet]. Tools.thermofisher.com. 2021 [cited 31 January 2021]. Available from: http://tools.thermofisher.com/content/ sfs/brochures/TR0065-ELISA-guide.pdf

[25] Chennaoui M, Gomez-Merino D, Drogou C, Geoffroy H, Dispersyn G, Langrume $\mathrm{C}$ et al. Effects of exercise on brain and peripheral inflammatory biomarkers induced by total sleep deprivation in rats. Journal of Inflammation. 2015 Sep 30;12(1):1-10. https://doi.org/ 10.1186/s12950-015-0102-3

[26] QIAzol Lysis Reagent - QIAGEN Online Shop [Internet]. Qiagen. 2013 [cited 13 November 2020]. Available from: https://www.qiagen.com/ca/products/ discovery-and-translational-research/lab-essentials/ buffers-reagents/qiazol-lysisreagent/\#orderinginformation

[27] Hernandez I, Sokolov B. Abnormal expression of serotonin transporter mRNA in the frontal and temporal cortex of schizophrenics. Molecular Psychiatry. 1997 Jan 1;2(1):57-64. https://doi.org/ $\underline{10.1038 / \text { sj.mp.4000215 }}$

[28] Khanzada F, Soomro N, Khan S. Association of Physical Exercise on Anxiety and Depression Amongst Adults [Internet]. 2015 [cited 31 January 2021]. Available from: http://doi.org/JCPSP, 25(7), 546-548.

[29] Morgan J, Olagunju A, Corrigan F, Baune B. Does ceasing exercise induce depressive symptoms? A systematic review of experimental trials including immunological and neurogenic markers. Journal of Affective Disorders. 2018;234:180-192.

[30] Winston, B., Lange-Carter, C., Gardner, A., Johnson, G. and Riches, D., 1995. Tumor necrosis factor alpha rapidly activates the mitogen-activated protein kinase (MAPK) cascade in a MAPK kinase kinase-dependent, c-Raf-1-independent fashion in mouse macrophages. Proceedings of the National Academy of Sciences.1995 Feb 28;92(5):1614-1618. https://doi.org/ $\underline{10.1073 / \text { pnas.92.5.1614 }}$ 
UNDERGRADUATE RESEARCH IN NATURAL AND CLINICAL SCIENCE AND TECHNOLOGY (URNCST) JOURNAL Read more URNCST Journal articles and submit your own today at: https://www.urncst.com

\section{Article Information}

Managing Editor: Jeremy Y. Ng

Peer Reviewers: Emma Nicholson, Prashanth Velayudhan

Article Dates: Received Nov 14 20; Accepted Feb 21 21; Published May 0621

\section{Citation}

Please cite this article as follows:

Gunabalasingam J, Aggarwal K. The effect of exercise on reducing tumor necrosis factor alpha levels and attenuating serotonin transporter gene expression: A research protocol. URNCST Journal. 2021 May 06: 5(5).

https://urncst.com/index.php/urncst/article/view/224

DOI Link: https://doi.org/10.26685/urncst.224

\section{Copyright}

(C) Janany Gunabalasingam, Kajol Aggarwal. (2021). Published first in the Undergraduate Research in Natural and Clinical Science and Technology (URNCST) Journal. This is an open access article distributed under the terms of the Creative Commons Attribution License (https://creativecommons.org/licenses/by/4.0/), which permits unrestricted use, distribution, and reproduction in any medium, provided the original work, first published in the Undergraduate Research in Natural and Clinical Science and Technology (URNCST) Journal, is properly cited. The complete bibliographic information, a link to the original publication on http://www.urncst.com, as well as this copyright and license information must be included.

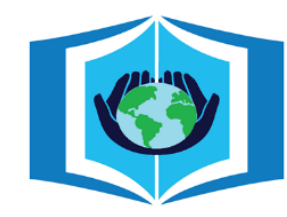

\section{URNCST Journal \\ "Research in Earnest"}

\section{Funded by the Government of Canada}

\section{Canadà̀}

Do you research in earnest? Submit your next undergraduate research article to the URNCST Journal!

| Open Access | Peer-Reviewed | Rapid Turnaround Time | International |

| Broad and Multidisciplinary | Indexed | Innovative | Social Media Promoted |

Pre-submission inquiries? Send us an email at info@ urncst.com | Facebook, Twitter and LinkedIn: @URNCST

Submit YOUR manuscript today at https://www.urncst.com! 